する改良点を考察した。

ユーザオリエンティテッドな装置とは，種々な使用環境 においてす装置機能が柔軟に対処でき，しかも使用者の 意図する方向に機能を規定できる装置である.

とのため，マイクロコンピュータを利用し，使用者の 判断基準を装置に採り入れるという観点加ら，i）術式 亿よる管球，焦点，撮影条件の規制，ii）メモり機能， iii）判断基集としての装值状態の表示等を行う. 又八一 ド的には，i）定管電圧方式，ii）管電流の自動調整， iii） $\mathrm{mA}, \sec の$ 連続制御等を丰現しした。 X線装置のシ ステム的側面の考察による新しい装置の提供が可能と雄 信する。

\section{9. 半導体検出器によるX線自動露出制御}

\section{東芝医用穖器事業部}

○小倉一郎・伊東克俊 · 木村 達

厚さが薄く，X線吸収が少なり薄形タイプで，採光野 選択の可能なX線自動露出制御用検出器として，シリコ シ放射線検出素子を組み込んだソりッドタイマーシステ ムを試作し，特性評価を試みた。厚さ $5 \mathrm{~mm}, \mathrm{X}$ 線吸収 約 $0.5 \mathrm{~mm}$ Alegv.で，組み込まれた 3 個のシリコン素子 は，操作部の押しボタンで任意の組み合わせ選択が可能。 特性評洒の結果, ソリッドタイマー制御器にて; 種々の 補正を行うことにより，5msec.ないしはそれ以下の短時 間制御が可能で，又管電圧変化に対しても好特性が得ら れた.とれらの結果，撮影部位に忍じた採光野を選択す るととにより，画翼を損なうことなく，撮影部位に合っ た適切な自動露出が可能亡なる。

350. I.I. 間接（コンデンサ式）装置の自動露出特性 北海道対がん協会検診センター放射線科 ○石岡，亮・中島玲子・斉藤文男 速水宏行: 三上真弘 $\cdot$ 五十萭正一 水野 盛・村田 薰

胃集団検彰の場合，条件設定の媔雑さを少なくするた め自動露出装置を最大限に利用することが重要である. 今回 I.I. 間接コンデンサ装置の自動露出特性を電気的に 測定を加えることによりその過渡現象を分析し検討を加 えた，線啠特性については受光部と撮影系が同一発光体 による為ほぼ良好であった。 phototimer しゃ断遅れ時間

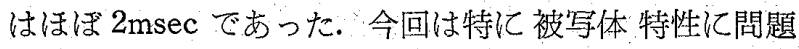
があったためつィルタの付加や撮影管電流を変えること により特性の改善を計った。ささらに phototimer 回路の 調整により同一条件下で広籍囲の被写体厚て適応可能な 特性を得るととができ，至適撮影条件の設定に利用し た.
351.コンデンサ装置における透視輝度自動制御

島津製作所医用技術部

○剤藤：章? 柴田邦夫

透視の輝度を自動制御するために従来より管電流を一 定にし，管電圧だけを変化させる方法が用いられている が，コンデンサ式X線高圧装置においては，高圧コンデ ンサの充放電特性の影響により，管電在を急速に変化さ せる事は困難である。そのためコンデンサ装置における 透視輝度自動制御认おいて，管電流制御方式を採用し， その特性を検討した。被写体厚特性，応答時間特性，ま た被ばく線量における管電死制御方式との比較等を検討 した結果，コンデンサ式装置が主に集団検診用として用 いられている現状からして，その操作性の簡便化を計る 上で管電流制御に依る透視輝度自動制御方式は，かなり 有用な手段であるという結論が得られた。

\section{座長集約}

との演題群の中の共通した部分を大別すると次の様に なる．1）受光部の試作及びその改良並びに応用，2）制 御器の諸特性の改善 (バリウム被覆特性，応答時間特 性)，3）連続撮影に於汀る自動露出，4）透視煇度自動 調整（コンデンサ式）５）X線装置の展望.

1）344番，345番，349番が該当する：344番は亱接撮 影用の検出部をそのまま間接撮影（ミラーカメラ）に応 用した結果の報告であるが，実睮的な諸特性は充分実用 に供され良好な結果を得ている，出来れば，臨床面でど の程度バラッキを無くすととが出来たか雨装置での比較 が欲しい. 345 番は胸部写真の濃度のバラツキを娍少さ せる為，側面尃用の受光部を設けた 3 分割採光方式をと り，整準偏差值加ら見て有意性のある一方式である. 349 番は受光部そのものの全く新しいソリッドタイプのもの で，検出部をより溥く，又，小型化するととか出来，拢 大率の改善にもつながる。

2) 346番と350番加該当する．346番は消化器系撮影時 のバリウム被覆度を透視情報 (TV 系) より判断し， そ の特性の改善を図っている。乙の方法はバリウムの被覆 による写真濃度の上昇はある程度防止出来ても, 陰性造 影又はその他の要因による写真濃度の低下を来たす場合 の刘応が今ところなされていない，又，被覆率か 100 \%の場合の補正加はっきりせず（質問 独協医大 松村 氏）被覆面積だけでなく，採光野に対す被覆率も並記し た方が良いと思う。臨床的に実証されておらず（質問 神奈川県立成人病センター 村西氏）今後早急な開発を 期待する. 350番はコンデンサ式の I.I. 間接での諸特性, 特応答時間特性の改善の報告で，その対策として，設 